\title{
Korvaavien sointujen käyttö jazzissa - funktioanalyyttinen näkökulma
}

Suurin osa jazzin teoriaa käsittelevästä kirjallisuudesta perustuu siihen, että jazzmusiikin vakiintuneet käytännöt on muotoiltu eksplisiittisiksi säännöiksi. Sääntöjä ei kovinkaan usein perustella teoreettisesti, jolloin niistä ei muodostu yhtenäistä kokonaisuutta. Yksi harvoista poikkeuksista on George Russellin kirja The Lydian Chromatic Concept of Tonal Organization (1959), jossa Russell esittää yhtenäisen teorian jazzin harmoniasta lähtien liikkeelle lyydisistä asteikoista. Russellin teoria on vaikuttanut erityisesti asteikkopohjaisen improvisoinnin kehitykseen. Russellin teoria on kuitenkin saanut osakseen runsaasti kritiikkiä. Sitä voidaankin pitää ainoastaan länsimaisen tonaalisen järjestelmän erään osa-alueen uudelleentulkintana, joka ei kykene selittämään kaikkea tonaalista jazzia (Jeanquartier 1984, 41).

Korvaavien sointujen käyttö on ollut jo 1930-luvulta lähtien olennainen osa jazzsäveltämistä ja -sovittamista. Monet uudet sävellykset on tehty käyttämällä runkona toisia jazzsävellyksiä tai 30-40-luvun populaarisävelmiä, joihin on tuotu omaleimaisuutta sointukorvausten avulla. Osa sointukorvauksista löydettiin teoreettisen pohdiskelun kautta, mutta merkittävä osa syntyi kokeilemalla. Muusikot korvasivat alkuperäisiä sointuja toisilla ja kuuntelivat lopputulosta. Parhaat ratkaisut vakiintuivat vähitellen yleiseksi käytännöksi.

Säveltämisen ja sovittamisen lisäksi sointujen korvausta käytetään myös improvisoinnissa, jolloin kappaleen sointurunkoon tuodaan vaihtelua ja monipuolisuutta korvaamalla alkuperäisiä sointuja toisilla. Sointukorvaussääntöjä voidaan tietenkin käyttää improvisoinnissa myös toiseen suuntaan. Jos sävellyksessä tai sovituksessa on käytetty runsaasti korvaavia sointuja, ne voidaan improvisoitaessa korvata alkuperäisillä, yksinkertaisemmilla soinnuilla.

Jazzkirjallisuudesta löytyy lukuisia sointujen korvaussääntöjä, jotka ovat kuitenkin usein sisällöltään ristiriitaisia. Amerikkalainen jazztutkija Steven Strunk onkin kritisoinut jazzkirjallisuuden korvaussääntöjä, joissa annetaan ymmärtää, että "mikä tahansa sointu voidaan korvata lähes millä soinnulla tahansa, ja vieläpä musiikillisesta kontekstista riippumatta" (Strunk 1988, 490). Jazzkirjallisuuden korvaussääntöjen suurin ongelma on kuitenkin siinä, ettei säännöille yleensä esitetä mitään perusteluita. On kuitenkin hyvin todennäköistä, että tonaalisessa jazzissa useimmat sointukorvaukset perustuvat siihen, että korvaava sointu toteuttaa ainakin osittain saman funktion kuin alkuperäinen sointu. 
Tässä tutkimuksessa käytettiin taidemusiikin funktioanalyysia jazzin korvaavien sointujen tutkimiseen. Analyysimenetelmäksi valittiin Diether de la Motten kehittelemä menetelmä, jonka hän on muotoillut kirjassaan Harmoniaoppi (1987). De la Motten funktioanalyysi tarjoaa teoreettisen pohjan, jonka avulla voidaan muodostaa yhtenäinen käsitys korvaavien sointujen käytöstä jazzissa.

Tutkimuksen pääaineiston muodostivat tärkeimpien jazzpedagogien, kuten David Bakerin ja Jerry Cokerin kirjoittamat jazzin oppikirjat, joissa käsitellään tonaalista jazzia. Tässä mielessä tutkimus perustui tavallaan sekundääriaineistoon: siinä analysoitiin jazzkirjallisuudessa esitettyjä korvaussääntöjä, joita voidaan pitää eräänlaisena yhteenvetona käytännön musiikissa esiintyvistä sointukorvauksista. Toinen mahdollisuus olisi ollut analysoida käytännön musiikkiesimerkkejä, mutta tällöin aineiston olisi pitänyt olla huomattavasti laajempi, jotta olisi päästy samaan kattavuuteen.

Tutkimukselle asetettiin kaksi tavoitetta. Toisaalta oli tarkoitus muodostaa yhtenäinen, kompakti teoria korvaavien sointujen käytöstä jazzissa. Toisaalta tavoitteena oli tutkia de la Motten funktioanalyysin soveltuvuutta jazzanalyysiin.

Nuottiesimerkeissä olevat soinnut on merkitty selkeyden takia perusmuodossaan. Todellisuudessa jazzmuusikot eivät juuri koskaan soita sointuja perusmuodossaan. Esim. pianistit jättävät soinnuista pohjasävelet pois ja hajottavat muut soinnun sävelet haluamallaan tavalla.

\section{Diether de la Motten funktiomerkinnät}

De la Motten funktiomerkinnät perustuvat Wilhelm Malerin kehittämiin merkintöihin. De la Motte on kuitenkin lisännyt joukkoon muutaman oman merkintänsä, jottei Bachin ajan sointuja tarvitse kuvata paljon myöhemmin syntyneiden sointujen johdannaisiksi ja jotta samalla voitaisiin kuvata myös eri funktioiden sekoittuminen (Motte 1987, 7). Seuraavassa esitellään lyhyesti de la Motten merkintöjen pääperiaatteet.

Sointujen funktiomerkintä perustuu kolmeen perusfunktioon: toonikaan (T), subdominanttiin (S) ja dominanttiin (D). Duurimuotoisia sointuja merkitään isolla kirjaimella (T, S, D) ja mollimuotoisia pienellä kirjaimella $(t, s, d)$. Numero funktiomerkinnän alakulmassa osoittaa, mikä sointu- tai lisäsävel on bassossa, esim. soinnussa $\mathrm{S}_{3}$ on terssi bassossa.

Funktiomerkinnän yläkulmaan kirjoitettu numero kertoo, että sointuun on lisätty sävel, esim. $\mathrm{D}^{7}$ on dominanttiseptimisointu ja $\mathrm{S}^{6}$ subdominantti, jossa on seksti kvintin tilalla. Jos soinnussa on sekä seksti että kvintti, merkitään nämä molemmat näkyviin, esim. $\mathrm{S}_{5}{ }^{6}$. Kun soinnun säveliä muunnetaan, merkitään alennusta merkillä "> "ja ylennystä merkillä "<", esim. soinnussa s ${ }^{6>}$ on alennettu seksti (ns. napolilainen sekstisointu, jota merkitään myös $\mathrm{s}^{\mathrm{n}}$ ). 
Kaarisulkeisiin asetettu sointu tai soinnut ovat merkkinsä ilmaisemassa funktionaalisessa suhteessa jäljessään seuraavaan sointuun, esim. (D)D on dominanttiin johtava välidominantti, jota merkitään myös $\mathrm{D}^{\mathrm{D}}$. Harhapurkauksissa merkitään hakasulkeisiin se sointu, johon edellisen soinnun olisi pitänyt purkautua.

Terssisukuiset soinnut sijaitsevat pienen tai suuren terssin päässä perussoinnun ylä- tai alapuolella. Terssisukuiset soinnut voidaan jakaa neljään ryhmään (Motte 1987, 145):

1) Paralleelisoinnut, joilla on kaksi yhteistä säveltä perussoinnun kanssa. Esimerkiksi T:n paralleelisoinnut ovat $\mathrm{Tp}$ ja $\mathrm{Tg}$, ja t:n paralleelisoinnut ovat $\mathrm{tP}$ ja $\mathrm{tG}$.

2) Variantin paralleelisoinnut, joilla on yksi yhteinen sävel. Variantilla tarkoitetaan duurissa samalle pohjasävelelle rakentuvaa mollisointua ja mollissa samalle pohjasävelelle rakentuvaa duurisointua. Esimerkiksi T:n variantin paralleelisoinnut ovat $\mathrm{tP}$ ja $\mathrm{tG}$, ja suhteessa t:aan vastaavasti $\mathrm{Tp}$ ja $\mathrm{Tg}$.

3) Paralleelisointujen variantit, joilla on myös yksi yhteinen sävel. Esimerkiksi T:n paralleelisointujen variantit ovat sen duurisoinnuiksi muunnetut paralleelit TP ja TG, ja vastaavasti suhteessa t:aan sen mollisoinnuiksi muunnetut paralleelit tp ja tg.

4) Variantin paralleelisointujen variantit, joilla ei ole yhteisiä säveliä perussoinnun kanssa. Esimerkiksi suhteessa T:aan näitä ovat tp ja tg, ja vastaavasti suhteessa t:aan TP ja TG.
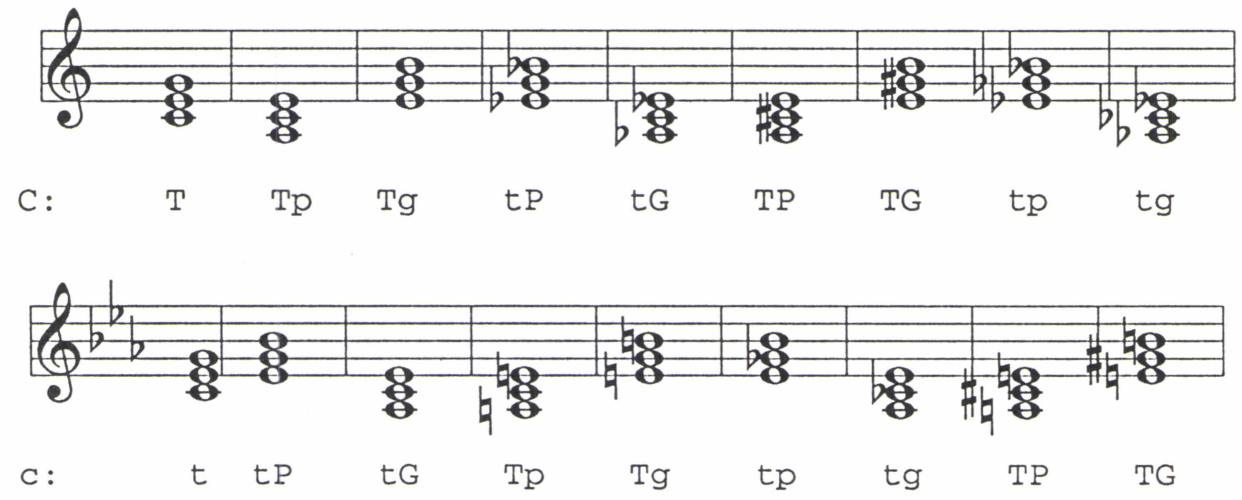

Nuottiesimerkki 1.

Mollitoonikaan purkautuvaa vähennettyä septimisointua merkitään ${ }^{\mathrm{s}} \mathrm{D}^{\mathrm{v}}$. Merkintä osoittaa, että vähennetyssä septimisoinnussa on paitsi dominantin, myös subdominantin piirteitä. Vähennetty septimisointu voi purkautua mollitoonikan lisäksi myös duurimuotoiseen toonikaan. Jos vähennetty sointu purkautuu dominanttiin, käytetään merkintää $\mathrm{D}^{\mathrm{D}^{\mathrm{v}}}$. Tässä tapauksessa soinnussa on paitsi dominantin dominantin, myös toonikan piirteitä. Vähennetyn soinnun ${ }^{s} D^{v}$ säveliä merkitään käännöksissä ja muunnoksissa numeroilla 1, 3, 5 ja 7 . 
Funktioanalyyttisen lähestymistavan soveltamisessa jazzanalyysiin on muutamia käytännön ongelmia. Jazzsävellysten sointumerkit ovat vain ohjenuora esittäjälle, joka tuskin koskaan soittaa täysin niiden mukaisesti. Soinnut merkitään yleensä aina perusmuodossa, vaikka esittäjä saattaakin soittaa niiden käännöksiä. Esittäjä saattaa myös lisätä sointuun lisäsäveliä, kuten noonin, undesimin tai tredesimin, vaikkei niitä olekaan merkitty sointumerkintään. Esimerkiksi toonikaa ei yleensä koskaan soiteta tavallisena kolmisointuna, vaan siihen lisätään lähes aina suuri septimi tai suuri seksti.

Sointujen käännökset ja lisäsävelet eivät kuitenkaan yleensä vaikuta jazzin harmoniseen perustaan, vaan niitä käytetään ainoastaan tuomaan vaihtelua sointiväriin. Tästä syystä ne voidaan useimmiten jättää huomioimatta analyysissa, jottei funktiomerkinnöistä tule liian monimutkaisia.

\section{Dominantin korvaukset}

Jazzin ehkä yleisin sointukorvaus on ns. tritonuskorvaus, jossa dominanttiseptimisointu korvataan toisella dominanttiseptimisoinnulla, jonka pohjasävel on tritonuksen etäisyydellä alkuperäisen soinnun pohjasävelestä (esim. Rinzler 1989, 94; Baker 1990, 120). Tritonuskorvauksessa korvaavan soinnun terssi on alkuperäisen soinnun septimi ja päinvastoin. Molemmissa soinnuissa on siis sama terssin ja septimin välinen tritonus, joka on olennainen dominanttiseptimisoinnun sointivärille. Tritonuskorvaus voidaan tehdä sekä dominantille että välidominantille:
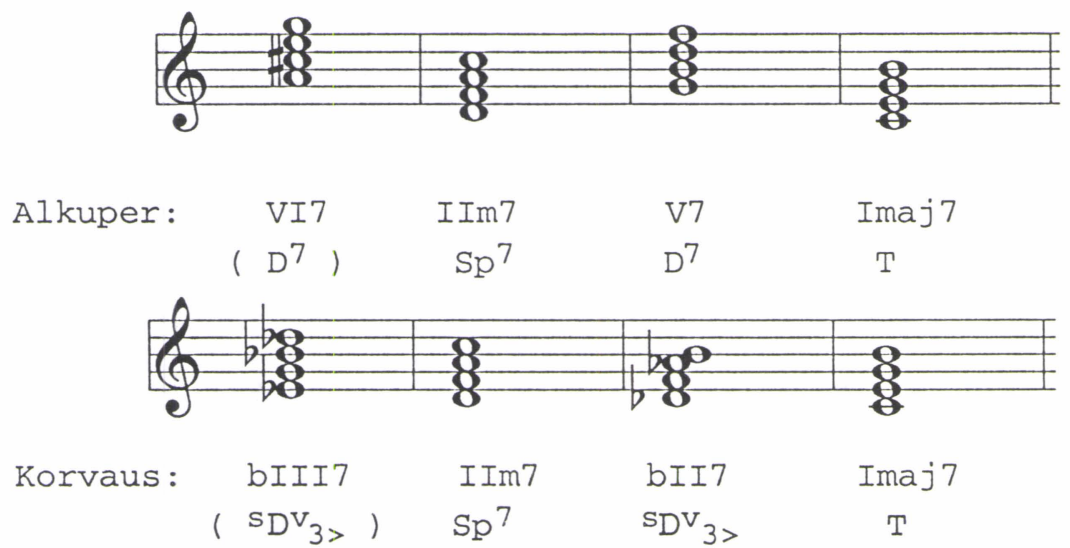

\section{Nuottiesimerkki 2.}

Tritonuskorvaus voidaan tulkinta vähennetyn soinnun muunnesoinnuksi, vaikka sointu soikin kuten dominanttiseptimisointu. Tulkintaa puoltaa myös se, että wieniläisklassismissa esiintyy tritonuskorvausta vastaava tilanne, jossa dominanttia edeltää dominanttiseptimisointu, jossa on dominantille tähtäävä yläpuolinen johtosävel (Motte 1987, 136). Tämän soinnun de la Motte tulkitsee $\mathrm{D}^{\mathrm{D}}{ }_{3>}^{\mathrm{v}}$-soinnuksi, vaikka se soikin kuten dominanttiseptimisointu. 
Tritonuskorvaussääntö voidaan Daniel Riciglianon $(1969,51)$ mukaan laajentaa käsittämään myös molliseptimi- ja puolivähennetyt soinnut. Hänen mukaansa mikä tahansa molliseptimi- tai puolivähennetty sointu voidaan korvata sen pohjasävelestä tritonuksen päässä olevalla dominanttiseptimisoinnulla. Tämä korvaussääntö tuntuu kuitenkin liian yleiseltä, sillä siinä ei oteta huomioon musiikillista kontekstia. Jos molliseptimisointu on dominanttia edeltävä subdominantti IIm7, tuottaa tritonuskorvaus soinnun bVI7:

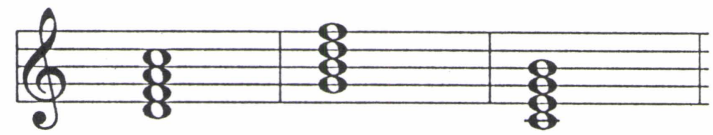

$\begin{array}{lllc}\text { Alkuper: } & \operatorname{IIm} 7 & \mathrm{~V} 7 & \operatorname{Imaj7} \\ & \mathrm{Sp}^{7} & \mathrm{D}^{7} & \mathrm{~T}\end{array}$

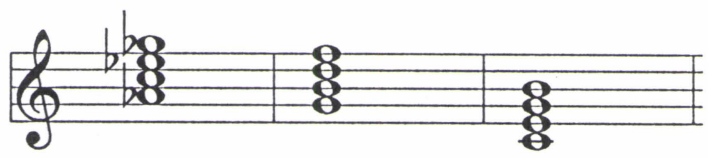

$\begin{array}{llll}\text { Korvaus: } & \text { bVI7 } & \text { V7 } & \text { Imaj7 } \\ & { }_{D^{D} V_{3>}} & D^{7} & T\end{array}$

\section{Nuottiesimerkki 3.}

Tässä tapauksessa tritonuskorvaus toimii, sillä se tuottaa dominantille johtavan soinnun $\mathrm{t}^{\mathrm{D}} \mathrm{v}_{3>}$. Jos taas molliseptimisoinnusta edetään toiseen mollisointuun, kuten sointukulussa I-IIm7-IIIm7, ei tritonuskorvaus tunnu järkevältä:
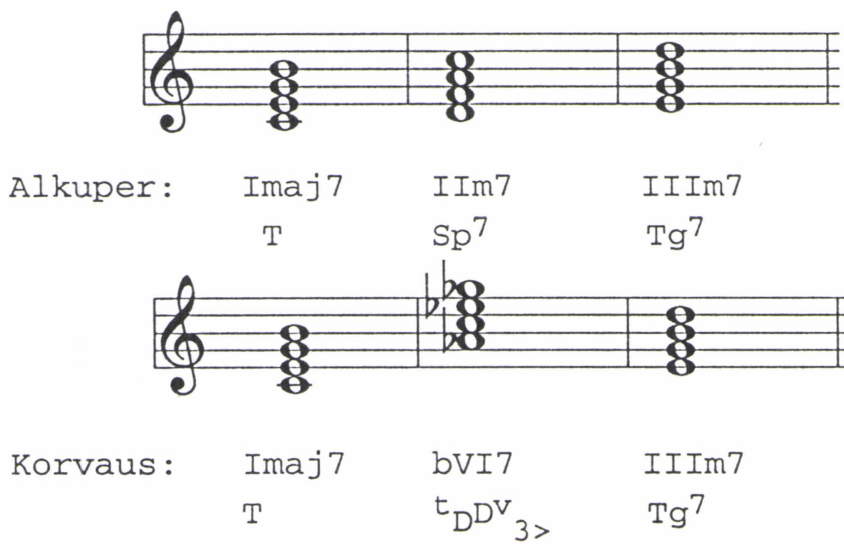

Nuottiesimerkki 4. 
Jälkimmäisessä esimerkissä tritonuskorvauksen käyttäminen muuttaa olennaisesti funktionaalista harmoniaa. Molliseptimisoinnulle ei siten voida tehdä tritonuskorvausta milloin tahansa, vaan musiikillinen konteksti täytyy ottaa huomioon.

1940-luvulta lähtien on jazzissa käytetty toisinaan subdominantin ja toonikan välissä sointua bVII7 (Potter 1989, 42). Subdominanttina on tällöin yleensä duuri- tai mollimuotoinen neljännen asteen sointu (IV tai IVm) ja toonikana Imaj7 tai IIIm7. Koska bVII7 sijaitsee subdominantin ja toonikan välissä, voidaan olettaa, että se toimii dominantin korvikkeena:

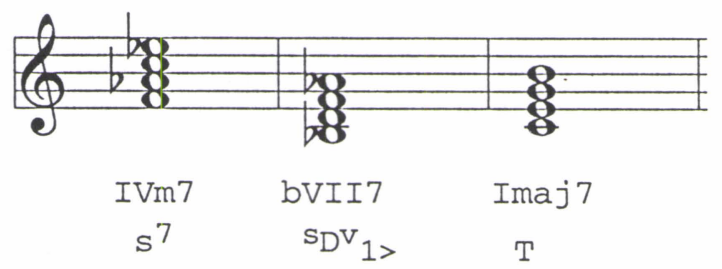

\section{Nuottiesimerkki 5.}

Sointu bVII7 voidaan siis tulkita vähennetyksi septimisoinnuksi ${ }^{\mathrm{s}} \mathrm{D}^{\mathrm{v}}$, jonka pohjasäveltä on alennettu. Vähennetyllä septimisoinnulla on dominanttiluonteen lisäksi myös subdominantin ominaisuuksia. Gary Potter $(1989,40)$ onkin pyrkinyt analysoimaan, voisiko bVII7-sointua käyttää myös subdominantin korvikkeena. Hän tulee siihen tulokseen, että vaikka bVII7-soinnulla on joissakin sointukuluissa subdominantin lineaarinen funktio eli sitä käytetään samassa kohtaa kuin subdominanttisointua, sillä ei kuitenkaan ole subdominantin harmonista funktiota.

Soinnun bVII7 käyttö dominantin korvikkeena palautuu siis vähennettyyn septimisointuun aivan samoin kuin tritonuskorvauskin. Sointua bVII7 ei kuitenkaan käytetä jazzissa dominanttina läheskään yhtä yleisesti kuin dominantin tritonuskorvausta bII7. Tämä voidaan selittää tarkastelemalla sointujen muunnesäveliä. Kun tritonuskorvaus tulkitaan vähennetyn soinnun muunnokseksi, soinnun muunnesävel toimii yläpuolisena johtosävelenä toonikan perussävelelle. Sillä on siten voimakas pyrkimys laskeutua toonikan perussäveleen. Sen sijaan bVII7-soinnussa toonikan alapuolista johtosäveltä on laskettu puoli sävelaskelta, mikä heikentää sen pyrkimystä nousta perussäveleen. Tritonuskor- 
vauksessa on siis voimakkaampi purkaustendenssi kuin bVII7-soinnussa, joten sitä käytetään paljon yleisemmin dominantin korvikkeena.

David Bakerin $(1990,120)$ mukaan dominantti V7 voidaan korvata sointujen bII7 (tritonuskorvaus) ja bVII7 lisäksi soinnulla III7. Baker muotoilee säännön, jonka mukaan dominanttiseptimisointu voidaan korvata toisella dominanttiseptimisoinnulla, jos niiden pohjasävelet ovat saman vähennetyn soinnun säveliä. Siten bII7, III7, V7 ja bVII7 ovat keskenään vaihdettavissa. Bakerin näkemys saa tukea myös funktioanalyysista:

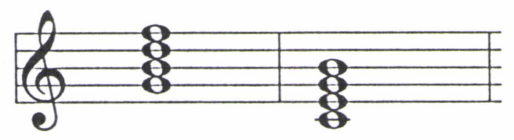

Alkuper: V7 Imaj7

$D^{7} \quad \mathrm{~T}$

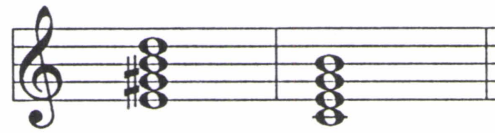

$\begin{array}{lll}\text { Korvaus: } & \operatorname{III7} & \operatorname{Imaj7} \\ & \mathrm{SDV}_{5>} & \mathrm{T}\end{array}$

\section{Nuottiesimerkki 6.}

Kuten havaitaan, myös III7 voidaan tulkita vähennetyksi septimisoinnuksi, jossa on muunnesävel. Kuitenkaan III7 ei esiinny jazzissa Gary Potterin (1989, 45) mukaan dominantin korvikkeena ainakaan bebopissa. Bakerin muotoileman säännön ja käytännön välinen ero voidaan selittää, kun tarkastellaan, mitä vähennetyn soinnun säveltä soinnussa III7 on muunnettu. Muunnettu sävel on sävellajin neljäs sävel (IV), jota on alennettu puoli sävelaskelta. Kun muuntamattoman vähennetyn soinnun sävel IV pyrkisi purkautumaan toonikan terssiin, ei muunnetulla sävelellä ole tätä pyrkimystä, sillä se on jo enharmonisesti sama sävel kuin toonikan terssi. Tästä syystä soinnulla III7 on paljon heikompi purkaustendenssi kuin soinnuilla bII7 ja bVII7, joten sitä ei yleensä käytetä dominantin korvikkeena.

Dominanttiseptimisointu voidaan David Bakerin $(1990,120)$ mukaan korvata myös vähennetyllä tai puolivähennetyllä soinnulla, joiden pohjasävel on suuren terssin verran alkuperäisen soinnun yläpuolella. Lisäksi korvaaviksi soinnuiksi kelpaavat kaikki kyseisen vähennetyn soinnun käännökset. Täten dominantti V7 voidaan korvata vähennetyllä soinnulla VII ${ }^{\circ}$ (tai sen käännöksillä $\left.\mathrm{II}^{\circ} 7, \mathrm{IV}^{0} 7 \mathrm{ja} \mathrm{bVI}^{\circ} 7\right)$ tai puolivähennetyllä soinnulla $\mathrm{VII}^{\circ} 7$ : 

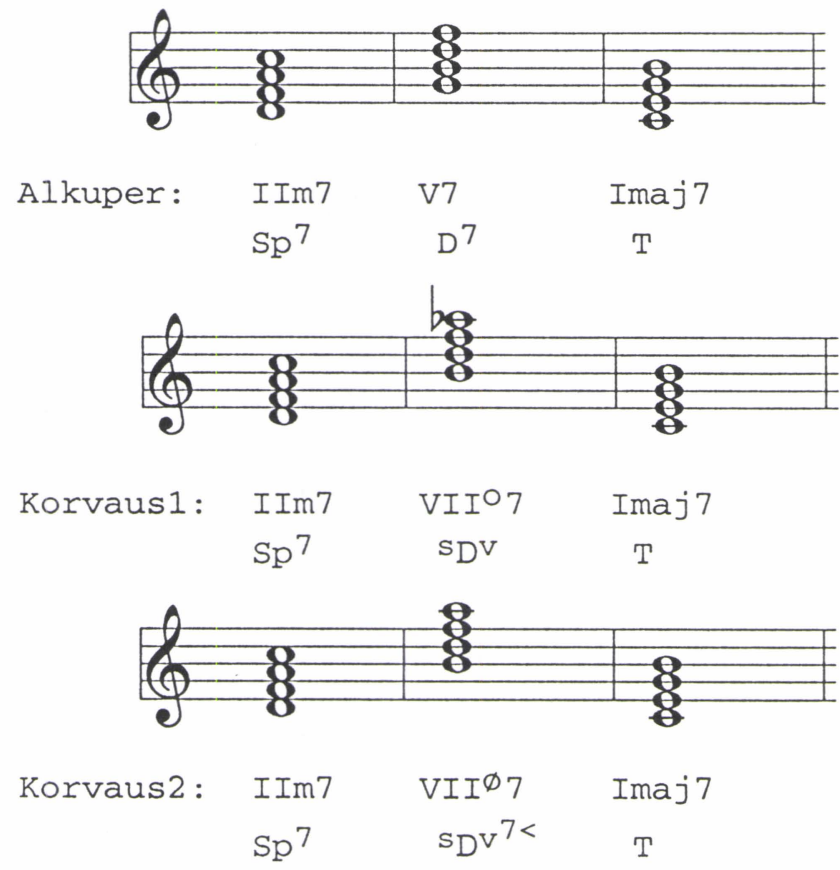

\section{Nuottiesimerkki 7.}

Funktioanalyysin kannalta sointu $\mathrm{VII}^{\circ} 7$ voidaan siis tulkita vähennetyksi soinnuksi ${ }^{\mathrm{s}} \mathrm{D}^{\mathrm{v}}$. Puolivähennetty sointu voidaan puolestaan tulkita vähennetyn soinnun ${ }^{\mathrm{s}} \mathrm{D}^{\mathrm{v}}$ muunnokseksi, jossa soinnun ylintä säveltä on ylennetty puoli sävelaskelta. Vaihtoehtoisesti sointu voidaan tulkita dominanttinoonisoinnuksi, josta puuttuu pohjasävel.

Kaikille edellä kuvatuille dominantin korvauksille on siis löydettävissä funktionaalisia perusteita. Kuitenkin David Baker muotoilee edellisten sääntöjen lisäksi kaksi dominantin korvaussääntöä, joiden perusteluja täytyy etsiä muuta kautta. Hänen mukaansa dominanttiseptimisointu voidaan korvata musiikillisesta kontekstista riippumatta molliseptimisoinnulla, jonka pohjasävel on kvartin verran alkuperäisen soinnun pohjasävelen alapuolella, tai duurisoinnulla, jonka pohjasävel on suuren sekunnin verran alkuperäisen soinnun pohjasävelen alapuolella (Baker 1990, 119). Bakerin antaman säännön mukaan dominantti V7 voitaisiin siis korvata soinnuilla IIm7 ja IVmaj7. Jazzissa erittäin yleiseen II-V-I-sointukulkuun sovellettuna korvaukset voidaan analysoida seuraavasti: 


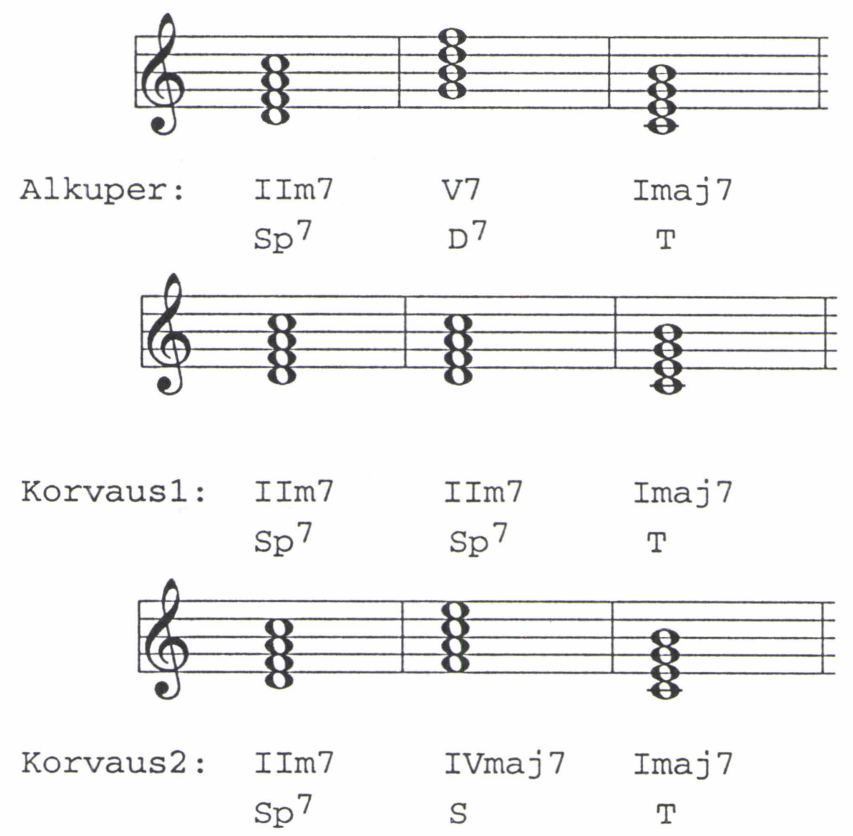

\section{Nuottiesimerkki 8.}

Tässä esimerkissä Bakerin korvaussääntöjen käyttäminen muuttaa siis selvästi sointukulun funktionaalista harmoniaa, sillä dominanttitehoinen sointu vaihtuu subdominanttitehoiseksi, jolloin vahva kadenssi muuttuu plagaaliseksi. Voidaankin ajatella, että nämä kaksi Bakerin korvaussääntöä on tarkoitettu enemmänkin tuomaan vaihtelua improvisointiin kuin harmonian muunteluun, sillä kummallekin säännölle löytyy perustelu asteikkopohjaisesta improvisoinnista. Kun improvisoidaan asteikkojen perusteella, molliseptimisoinnun yhteydessä soitetaan kaikkein yleisimmin doorinen asteikko ja dominanttiseptimisoinnun yhteydessä miksolyydinen asteikko (Coker 1987, 53). Tästä seuraa, että sointujen IIm7 ja V7 mukaisissa asteikoissa on täsmälleen samat sävelet. IVmaj7-soinnun yhteydessä taas käytetään yleensä IV asteelle rakennettua duuriasteikkoa, jonka neljäs sävel on ylennetty, jolloin myös sointujen V7 ja IVmaj7 asteikoissa on samat sävelet. Improvisoiva solisti voi siis soittaa sointujen IIm7 ja IVmaj7 asteikkojen mukaisia säveliä samalla kun rytmiryhmä soittaa sointua V7 ilman, että hän soittaisi soinnun V7 asteikkoon kuulumattomia säveliä. 


\section{Toonikan korvaukset}

Duurimuotoinen toonika Imaj7 korvataan usein soinnulla IIIm7. Soinnuilla on kolme yhteistä säveltä, sillä IIIm7 voidaan tulkita soinnuksi Imaj9, josta puuttuu pohjasävel (Rinzler 1989, 92). Funktioanalyysin kannalta sointu IIIm7 voidaan tulkita toonikan vastakkaissoinnuksi $\mathrm{Tg}^{7}$.

IIIm7-sointua käytetään yleisesti toonikan korvikkeena sointukulussa II-V-I, jolloin dominantti purkautuu soinnun Imaj7 sijasta sointuun IIIm7:

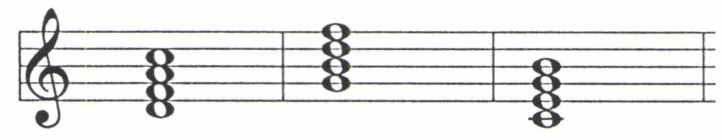

$\begin{array}{llll}\text { Alkuper: } & I I m 7 & \text { V7 } & \text { Imaj7 } \\ & \mathrm{Sp}^{7} & \mathrm{D}^{7} & \mathrm{~T}\end{array}$

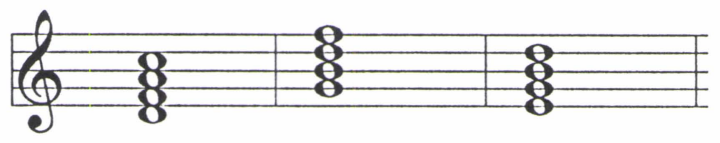

$\begin{array}{llll}\text { Korvaus: } & \operatorname{IIm} 7 \quad \mathrm{~V} 7 & \operatorname{IIIm7}\end{array}$

\section{Nuottiesimerkki 9.}

$\begin{array}{lll}\mathrm{Sp}^{7} & \mathrm{D}^{7} & \mathrm{Tg}^{7}\end{array}$

Toinen yleinen toonikan korvaussointu on toonikaparalleeli VIm7 (esim. Baker 1990, 117):
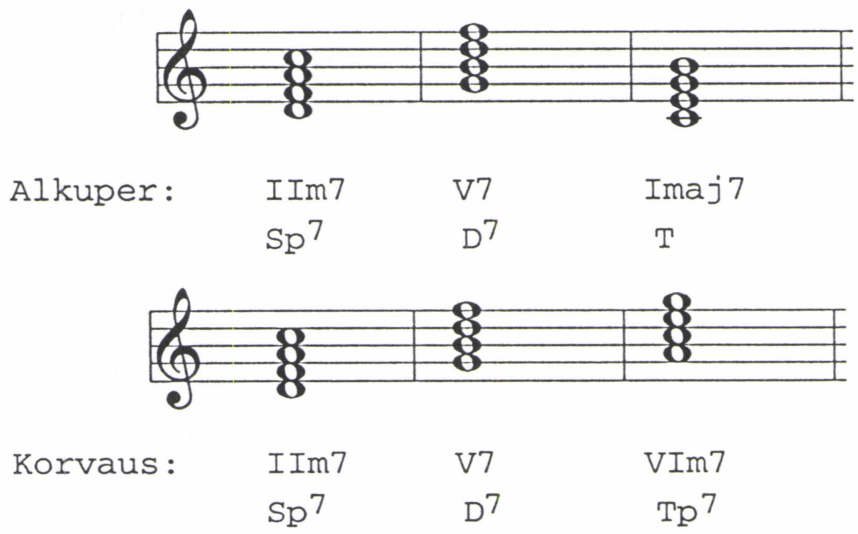

Nuottiesimerkki 10.

David Bakerin mukaan duurisointu voidaan korvata dominanttiseptimisoinnulla, jonka pohjasävel on kvartin verran alkuperäisen soinnun pohjasävelen yläpuolella ja johon on lisätty korotettu undesimi (Baker 1990, 118). Siten too- 
nikasointu Imaj7 voitaisiin korvata soinnulla IV7add+11. Tälle soinnulle on vaikea keksiä mitään sellaista funktioanalyyttistä tulkintaa, jonka mukaan se voisi toimia toonikan korvikkeena, sillä sointu on selvästi subdominanttitehoinen. Perustelut korvaukselle löytyvätkin jälleen asteikkopohjaisesta improvisoinnista. Soinnun IV7add+11 yhteydessä soitetaan yleensä ns. lyydinen dominanttiasteikko, joka on nousevan melodisen mollin neljännelle asteelle rakennettu asteikko (Baker 1990, 55). IV7add+11-soinnun yhteydessä soitetaan siis asteikko, jonka sävelet ovat IV, V, VI, VII, I, II ja bIII. Kuten huomataan, ainoa ero toonikan mukaiseen duuriasteikkoon on alennettu terssi bIII, joka voidaan tulkita bluesasteikon blue noteksi. Sointukorvausta voidaan siis käyttää solistin improvisoinnissa, mutta säestyksen sointuihin sovellettaessa korvaava sointu muuttaa olennaisesti kappaleen funktionaalista harmoniaa.

\section{Subdominantin korvaukset}

Jazzissa subdominanttina käytetään yleensä duurissa toiselle asteelle rakennettua subdominantin paralleelia $\mathrm{Sp}^{7}$ ja mollissa toiselle asteelle rakennettua sointua $s_{6}^{5}$. William Fowlerin $(1977,61)$ mukaan subdominanttina voidaan kuitenkin käyttää periaatteessa mitä tahansa sointua, jossa on mukana subdominanttisävel (IV), mutta ei toonikan johtosäveltä (VII). Tästä seuraa, että toiselle ja neljännelle asteelle rakennettujen sointujen lisäksi subdominanttina voidaan käyttää alennetulle toiselle asteelle rakennettuja sointuja bII ja bIImaj7:

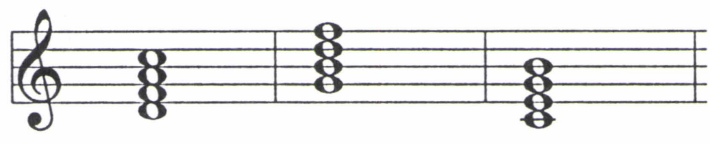

$\begin{array}{llcc}\text { Alkuper: } & \operatorname{IIm} 7 & \mathrm{~V} 7 & \operatorname{Imaj7} \\ & \mathrm{Sp}^{7} & \mathrm{D}^{7} & \mathrm{~T}\end{array}$

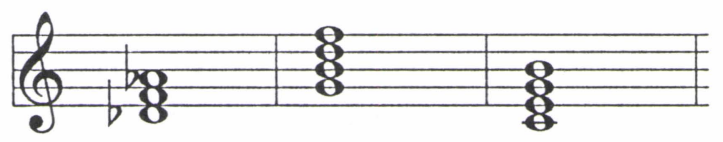

$\begin{array}{cccc}\text { Korvaus1: } & \text { bII } & \text { V7 } & \text { Imaj7 } \\ & \text { s } 6>^{7} & D^{7} & T\end{array}$

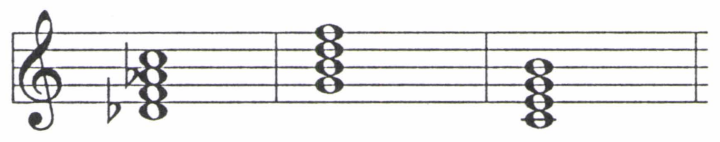

Korvaus2: bIImaj7 V7 $s^{5} 6>\quad D^{7} \quad \mathrm{~T}$

Nuottiesimerkki 11. 
Molemmat soinnut muistuttavat napolilaista sointua $\mathrm{s}^{\mathrm{n}}$, sillä niiden seksti on alennettu. Soinnut esiintyvät kuitenkin käännöksinä, joissa alennettu seksti on pohjasävelenä. Soinnussa bIImaj7 on alennetun sekstin lisäksi mukana kvintti. Molemmissa soinnuissa on siis subdominanttina paljon harmonista energiaa, sillä alennetulla sekstillä on voimakas purkaustendenssi dominantin kvinttiin.

David Bakerin $(1990,118)$ mukaan subdominantti IIm7 voidaan korvata soinnuilla V7 tai VII ${ }^{87}$ :

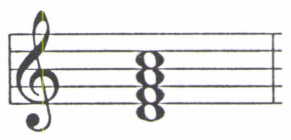

Alkuper: IIm7

$\mathrm{Sp}^{7}$

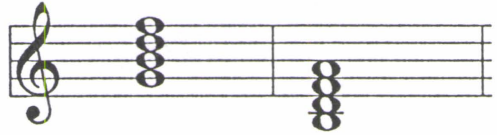

Korvaus: V7 / VII $\varnothing_{7}$

$\mathrm{D}^{7} \quad \mathrm{SDV}^{7<}$

\section{Nuottiesimerkki 12.}

Alkuperäinen subdominanttisointu korvataan siis selvästi dominanttitehoisella soinnulla, joten korvausta ei voi tehdä musiikillisesta kontekstista riippumatta. Sointukorvaus on kuitenkin perusteltavissa asteikkopohjaisen improvisoinnin näkökulmasta. Soinnun IIm7 mukaisessa doorisessa asteikossa ja soinnun V7 mukaisessa miksolyydisessa asteikossa on nimittäin samat sävelet. Puolivähennetyn soinnun yhteydessä voidaan soittaa lokrinen asteikko (Coker 1987, 42), jossa on myös samat sävelet. Asteikkopohjaisen improvisoinnin kannalta on siis samantekevää, valitaanko asteikko soinnun IIm7, V7 vai VII 7 perusteella. Jos Bakerin sääntöä puolestaan sovelletaan säestyksen sointuihin, se muuttaa selvästi sävellyksen funktionaalista harmoniaa.

Baker $(1990,119)$ tarjoaa soinnun IIm7 korvaukseksi myös vähennettyä sointua $\mathrm{II}^{\circ} 7$ ja sen käännöksiä $\mathrm{IV}^{\circ} 7, \mathrm{bVI}^{\circ} 7$ ja VII 7 : 


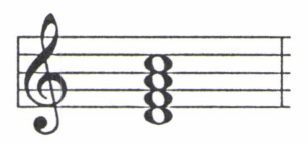

Alkuper: IIm7

$\mathrm{Sp}^{7}$

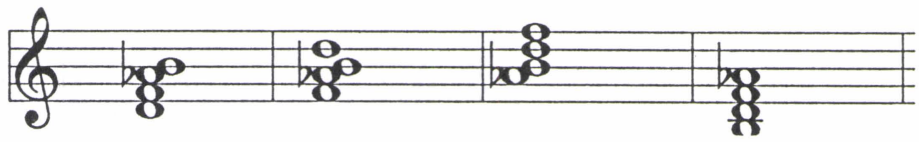

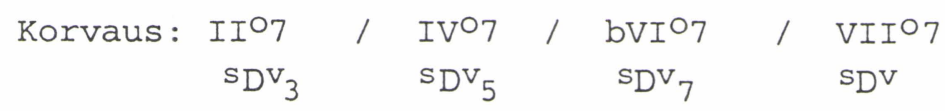

\section{Nuottiesimerkki 13.}

Koska vähennetyssä septimisoinnussa on dominantin lisäksi myös subdominantin piirteitä, korvausta voidaan pitää jossain määrin perusteltuna. Kuitenkin tämäkin Bakerin korvaus selittyy paremmin asteikkopohjaisen improvisoinnin perusteella. Molliseptimisoinnun yhteydessä voidaan nimittäin soittaa haluttaessa vähennetty asteikko (Coker 1987, 53). Vähennetty asteikko muodostuu peräkkäisistä koko- ja puolisävelaskelista:

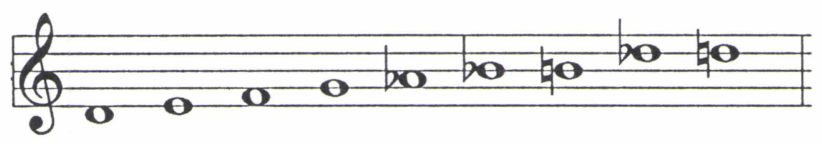

Nuottiesimerkki 14. Vähennetty asteikko.

Sen lisäksi, että toiselta asteelta alkavaa vähennettyä asteikkoa voidaan käyttää soinnun IIm7 yhteydessä, sitä voidaan käyttää myös vähennetyn soinnun $\mathrm{II}^{\circ} 7$ yhteydessä. Soinnun $\mathrm{II}^{0} 7$ käännöksien $\mathrm{IV}^{0} 7, \mathrm{bVI}^{\circ} 7$ ja VII ${ }^{\circ} 7$ mukaisissa asteikoissa on enharmonisesti samat sävelet. Asteikkopohjaisen improvisoinnin kannalta subdominantin korvaaminen vähennetyllä soinnulla palautuu siis vähennetyn asteikon käyttöön molliseptimisoinnun yhteydessä.

Bakerin $(1990,119)$ mukaan molliseptimisointu IIm7 voidaan korvata musiikillisesta kontekstista riippumatta II-V-sointukuluilla IVm7-bVII7, bVIm7-bII7 ja VIIm7-III7. Funktioanalyyttisesti nämä korvaukset voidaan tulkita II-V-sointukuluiksi, joissa jälkimmäinen dominanttiseptimisointu toimii vähennetyn soinnun ${ }^{\mathrm{s}} \mathrm{D}^{\mathrm{v}}$ muunnoksena. Esim. korvaus bVIm7-bII7 voidaan tulkita seuraavasti: 

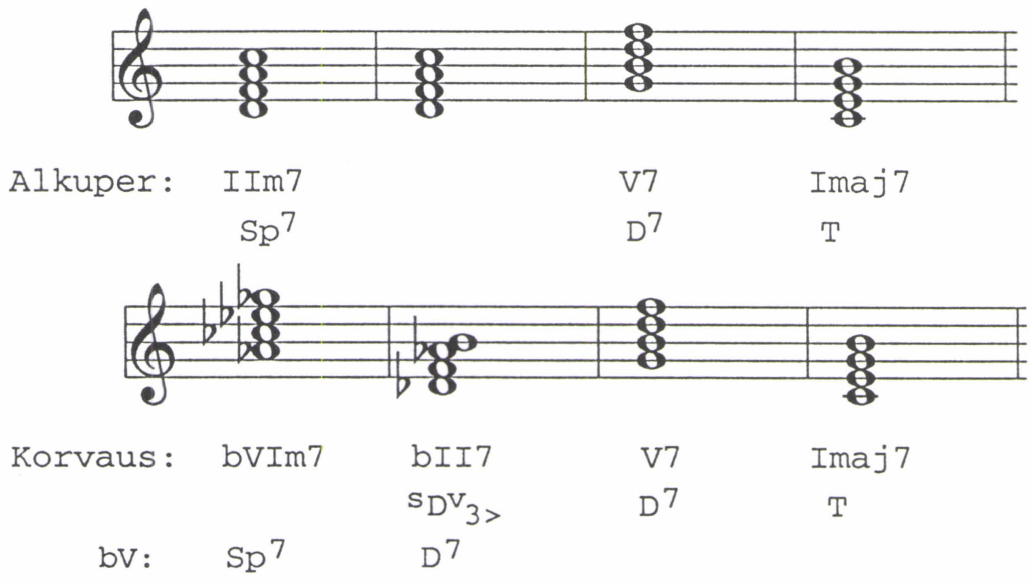

\section{Nuottiesimerkki 15.}

Tulkinnasta huomataan, ettei soinnun $\operatorname{IIm} 7$ korvauksia $\operatorname{IVm} 7-b V I I 7$, bVIm7-bII7 ja VIIm7-III7 pysty kovinkaan hyvin perustelemaan funktioanalyysillä, sillä subdominanttisointu korvataan dominantin korvikkeena toimivalla vähennetyllä soinnulla, jonka eteen on lisäksi lisätty toisen sävellajin subdominantti. Vaikka eteen lisätty molliseptimisointu tulkittaisiin pidätyssoinnuksi, ei subdominantin korvaaminen dominanttitehoisella soinnulla tunnu funktionaalisesti perustellulta. Sen sijaan nämäkin Bakerin korvaussäännöt ovat perusteltavissa asteikkopohjaisella improvisoinnilla ja vähennetyn asteikon käytöllä. Molliseptimisointujen IIm7, VIm7, bVIm 7 ja VIIm 7 mukaisissa vähennetyissä asteikoissa on nimittäin kaikissa enharmonisesti samat sävelet. Vähennettyä asteikkoa voidaan lisäksi käyttää dominanttiseptimisoinnun yhteydessä, jos asteikko aloitetaan puoli sävelaskelta dominanttiseptimisoinnun pohjasävelen yläpuolelta (Coker 1987, 53). Siten sointujen bVII7, bII7 ja III7 mukaisissa vähennetyissä asteikoissa on enharmonisesti samat sävelet kuin soinnun $\operatorname{IIm} 7$ mukaisessa vähennetyssä asteikossa. Sointu $\operatorname{Im} 7$ on siis asteikkopohjaisessa improvisoinnissa korvattavissa sointukuluilla IVm7-bVII7, bVIm7-bII7 ja VIIm7-III7, sillä kaikissa voidaan käyttää enharmonisesti täsmälleen samaa vähennettyä asteikkoa kuin soinnun IIm 7 yhteydessä.

Kaikki edelliset Bakerin subdominantin korvaussäännöt on siis selvästikin johdettu asteikkopohjaisen improvisoinnin periaatteista. Niille ei löydy funktionaalista perustelua, joten niitä ei voi soveltaa säestyksen sointuihin musiikillisesta kontekstista riippumatta. Sääntöjen soveltaminen improvisointiin voi kuitenkin olla perusteltua, sillä ne mahdollistavat esim. saman ulkoaopetellun fraasin käytön useiden eri sointujen yhteydessä. 


\section{Korvaavat sointukulut}

Edellä on analysoitu sääntöjä, joissa alkuperäinen sointu korvataan vain yhdellä soinnulla. Kuitenkin sointu voidaan korvata myös useamman soinnun muodostamalla sointukululla. Näistä kaikkein yleisin on II-V-sointukulku, jota voidaan käyttää esim. dominantin tai välidominantin korvikkeena. Duurissa se esiintyy muodossa IIm7-V7-Imaj7 ja mollissa muodossa II ${ }^{87}$-V7-Im6. Molemmissa sointukuluissa on hyvin voimakas harmoninen liike, joka johtaa toonikaan. Tästä syystä II-V-sointukulkua käytetään hyvin yleisesti toonikan tai välitoonikan edellä vahvistamaan pysyvää tai tilapäistä tonaalista keskusta. Jazzissa modulaatiot tehdään useimmiten juuri II-V-sointukulun avulla (Ricigliano 1969, 84).

Sointukulkua II-V käytetään yleisesti välidominanttina. Esimerkiksi toonikalta subdominantille siirryttäessä saatetaan väliin lisätä subdominanttiin purkautuva II-V-sointukulku:
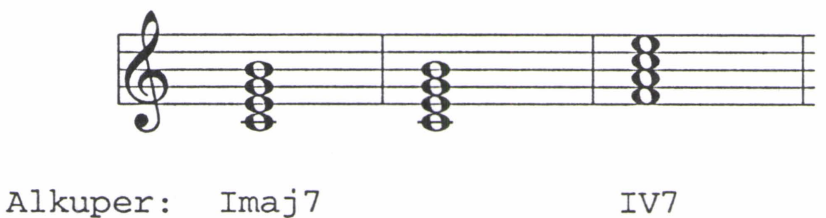

$\mathrm{T} \quad \mathrm{S}^{7}$

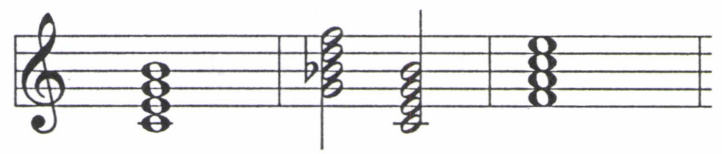

$\begin{array}{ccccc}\text { Korvaus: } & \operatorname{Imaj7} & \mathrm{Vm} 7 & \mathrm{I} 7 & \mathrm{IV7} \\ \mathrm{T} & \left(\mathrm{Sp}^{7}\right. & \left.\mathrm{D}^{7}\right) & \mathrm{S}^{7}\end{array}$

Nuottiesimerkki 16.

Kvinttiympyrän mukaiset välidominanttiketjut korvataan usein sävelaskelen välein laskevalla II-V-sointuketjulla. Tällöin dominanttiseptimisointu purkautuu seuraavan II-V-sointukulun molliseptimisointuun:

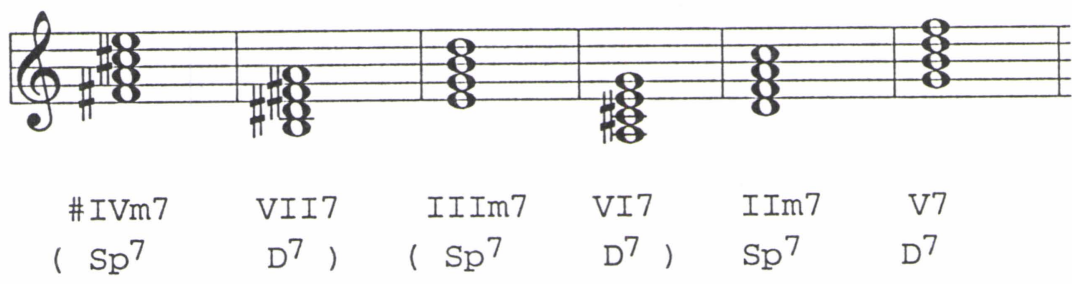

Nuottiesimerkki 17. 
Sointukulku II-V on niin vahva, että sitä saatetaan käyttää silloinkin, kun molliseptimisointu ei ole subdominanttisuhteessa dominanttiseptimisointua seuraavaan sointuun. Esim. dominantin tritonuskorvauksessa voidaan korvaavan soinnun eteen lisätä siihen II-V-suhteessa oleva molliseptimisointu:
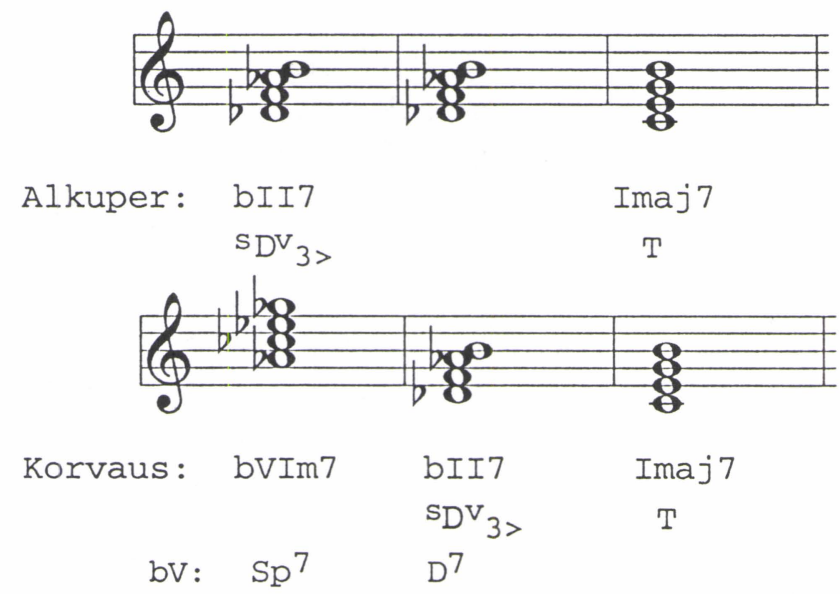

Nuottiesimerkki 18.

Tällöin molliseptimisointu ei ole harmonisesti itsenäinen, vaan se voidaan tulkita esim. pidätykseksi.

Dave Liebmanin $(1991,19)$ mukaan modernissa jazzissa voidaan kokeilla tietyn II-V-sointukulun korvaamista minkä tahansa toisen sävellajin II-V-kululla, joka kuitenkin purkautuu alkuperäisen sävellajin toonikaan. Esimerkiksi IIm7-V7-Imaj7-sointukulku voitaisiin tällöin korvata mm. sointukuluilla bIIIm7-bVI7-Imaj7 tai \#IVm7-VII7-Imaj7. Liebmanin ehdottamissa korvauksissa on kyse harhapurkauksista, joita ei välttämättä edes kannata yrittää analysoida funktionaalisesti, sillä ne eivät enää kuulu tonaalisuuden piiriin.

Korvaavia sointukulkuja käytetään yleisesti toonikan korvikkeena säkeistön eli choruksen viimeisissä tahdeissa. Tällaista korvaavaa sointukulkua nimitetään yleisesti turnaroundiksi. Se poistaa monotonisuutta ja luo harmonista jännitettä, joka purkautuu seuraavan choruksen ensimmäiseen sointuun. Lisäksi turnaround jäsentää kappaleen rakennetta, sillä choruksen viimeisiin tahteihin soitettu turnaround auttaa kuulijaa paremmin hahmottamaan, missä yksi chorus loppuu ja toinen alkaa. 
Hyvin yleinen turnaround-sointukulku on I-VI-II-V tai sen muunnokset (esim. Rinzler 1989, 95):
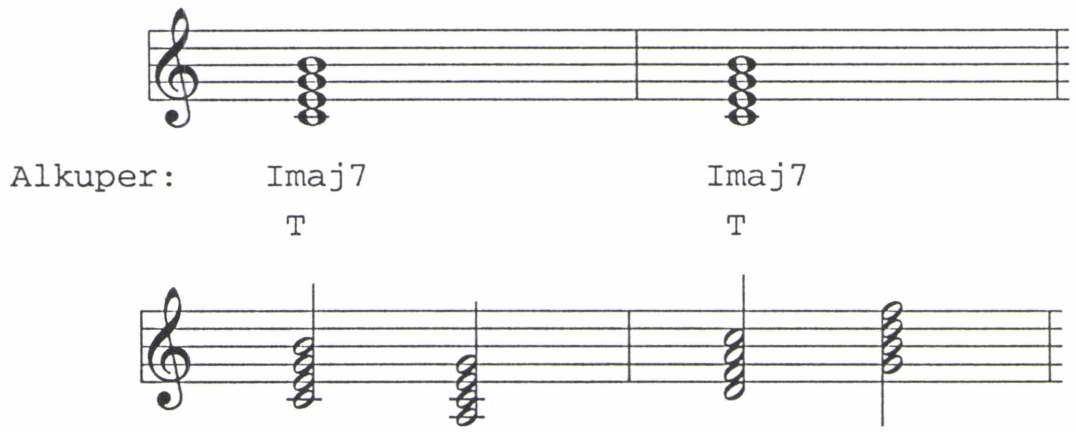

$\begin{array}{llrll}\text { Korvaus1: } & \operatorname{Imaj7} & \operatorname{VIm} 7 & \operatorname{IIm} 7 & \mathrm{V7} \\ & \mathrm{T} & \mathrm{Tp}^{7} & \mathrm{Sp}^{7} & \mathrm{D}^{7}\end{array}$
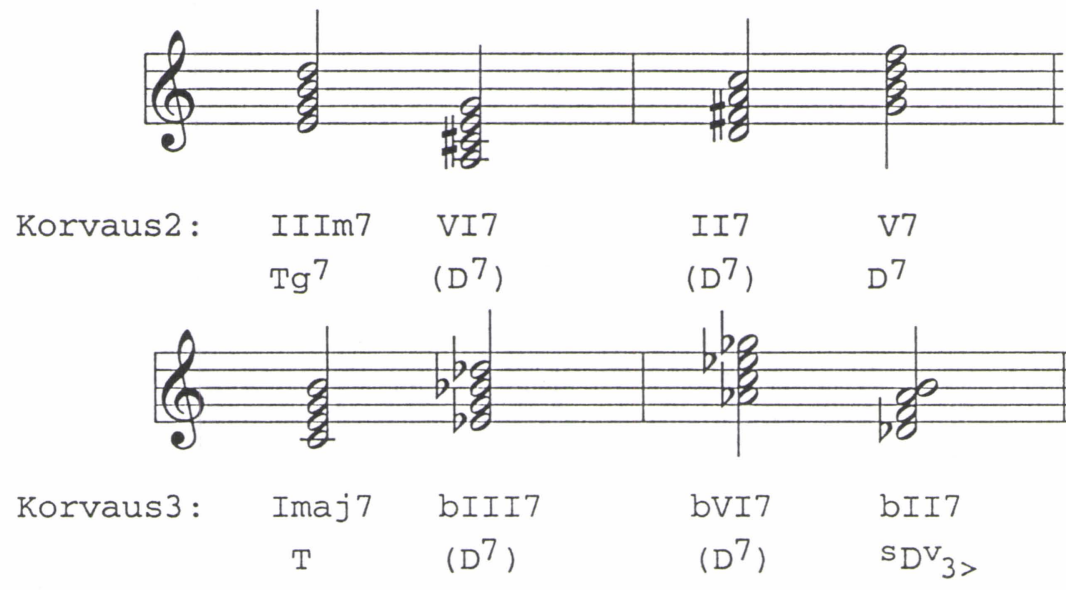

\section{Nuottiesimerkki 19.}

Sointukulusta I-VI-II-V voidaan muodostaa lisää turnaround-sointukulkuja esim. tritonuskorvausten ja välidominanttien avulla. Turnaroundina voidaan käyttää kuitenkin myös muita sointukulkuja. Jerry Coker $(1987,87)$ on luetellut muita yleisimpiä turnaround-sointukulkuja: 

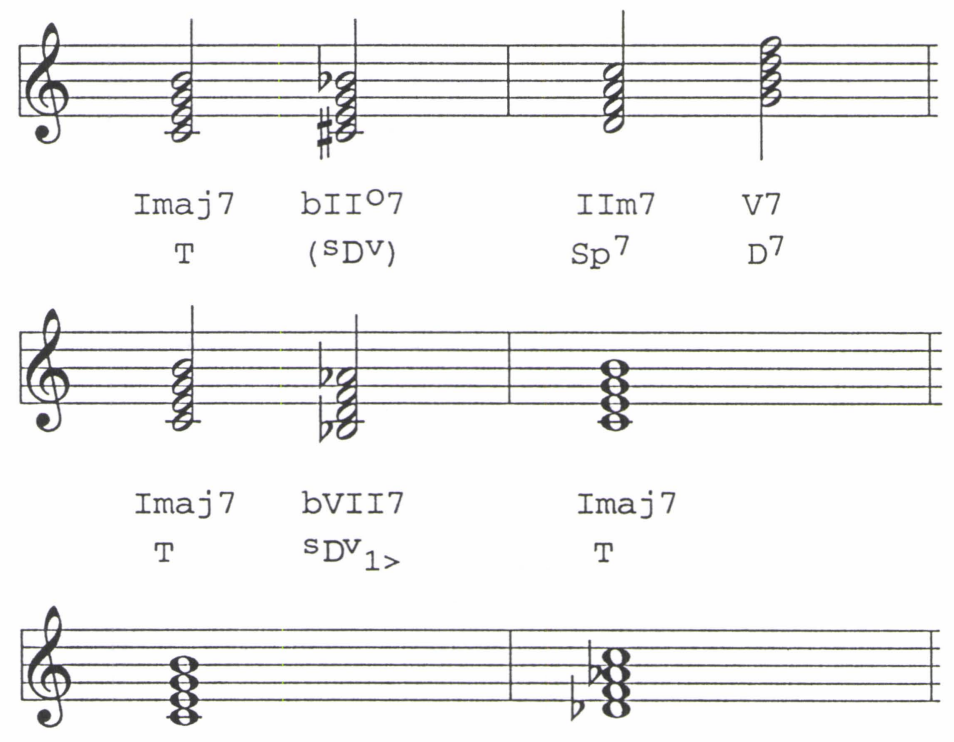

$\operatorname{Imaj} 7$

$\mathrm{T}$

bIImaj 7

$s^{5} 6>$

\section{Nuottiesimerkki 20.}

Ensimmäinen Cokerin luettelema turnaround on I-VI-II-V -sointukulun muunnos, jossa sointu VIm7 on korvattu sointuun IIm7 purkautuvalla vähennetyllä soinnulla. Toisessa turnaroundissa on kyse soinnun bVII7 käytöstä dominanttina, jolloin sointu voidaan tulkita vähennetyn soinnun muunnokseksi. Viimeisessä Cokerin turnaroundissa subdominanttitehoinen sointu bIImaj7 muodostaa plagaalisen kadenssin.

Varsin yleinen turnaround-sointukulku on edellisten lisäksi välidominanttiketju, joka johtaa sointuun bII (Collier 1977, 150):

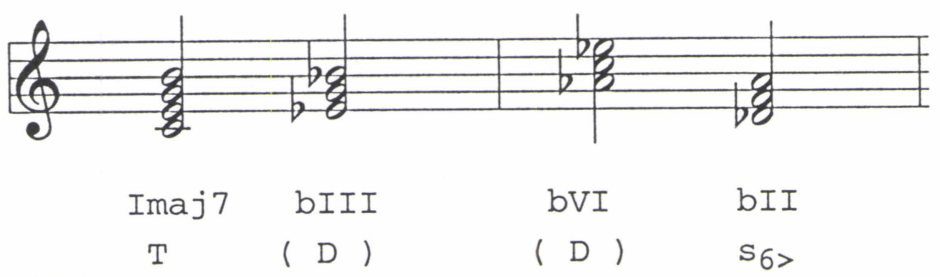

Nuottiesimerkki 21.

Soinnut bIII, bVI ja bII voivat olla tavallisia kolmisointuja, dominanttiseptimisointuja tai maj7-sointuja. Subdominanttitehoisista soinnuista bII ja bIImaj7 syntyy plagaali kadenssi, kun taas sointu bII7 on dominantin tritonuskorvaus, jolloin tuloksena on vahva kadenssi. 
John Coltrane kehitti vuonna 1959 myöhemmin legendaariseen maineeseen kohonneen korvaavan sointukulun II-V-I-sointukululle, kun hän teki korvauksien avulla kappaleesta Tune-Up oman sävellyksensä Countdown. David Baker $(1994,63)$ kutsuu Coltranen korvaavaa sointukulkua nimellä Countdown formula. Korvaava sointukulku on perusmuodossaan:
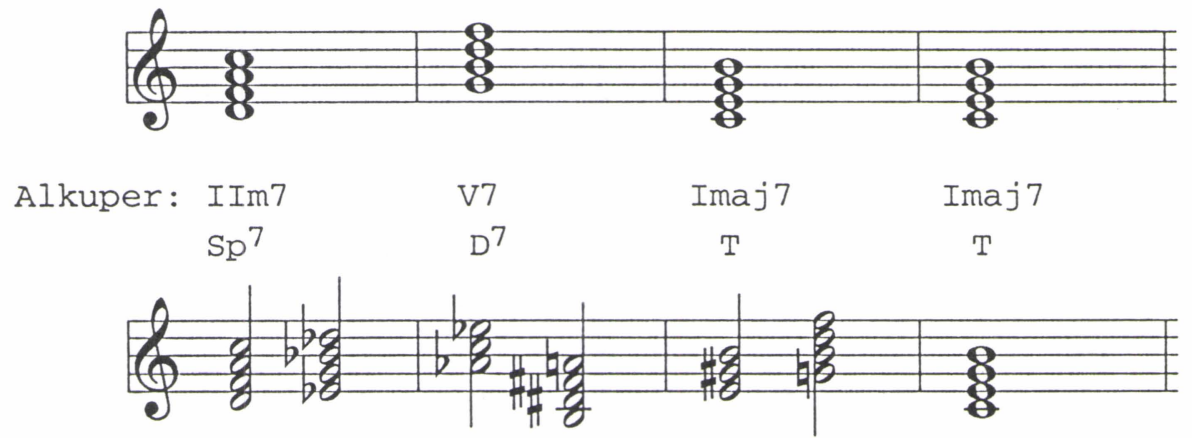

$\begin{array}{lllllllc}\text { Korvaus: } & \text { IIm7 } & \text { bIII7 } & \text { bVI } & \text { VII7 } & \text { III } & \text { V7 } & \text { Imaj7 } \\ & \operatorname{Sp}^{7} & \left(D^{7}\right) & \text { tG } & \left(D^{7}\right) & \text { TG } & D^{7} & \text { T }\end{array}$

\section{Nuottiesimerkki 22.}

David Liebmanin $(1991,20)$ mukaan Coltrane on käyttänyt myös seuraavaa Countdownin variaatiota:

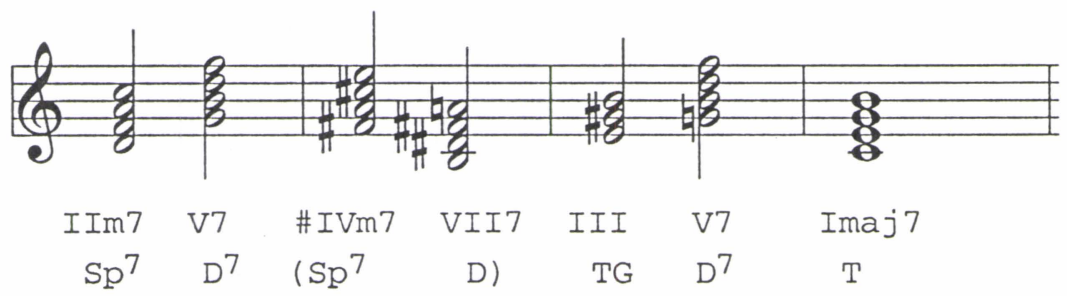

\section{Nuottiesimerkki 23.}

Perusmuotoa voidaan myös varioida lisäämällä dominanttiseptimisointujen eteen välisubdominantit:

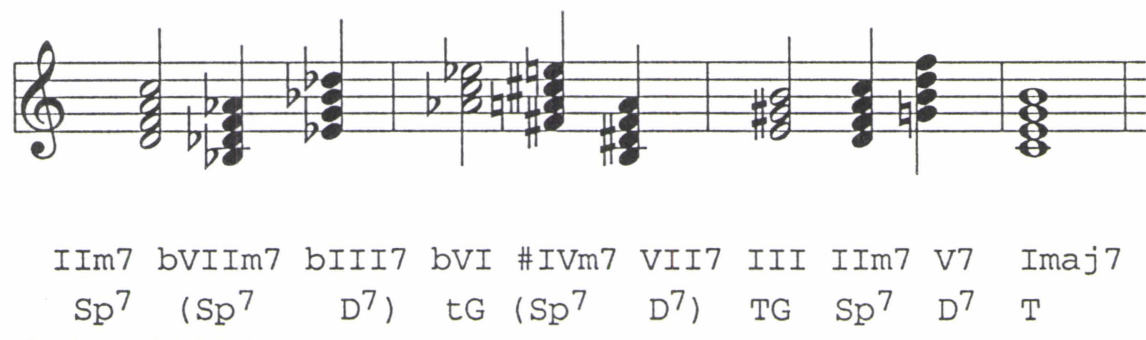

Nuottiesimerkki 24. 
Funktioanalyysi osoittaa parhaat puolensa Countdownin analyysissa, sillä sen avulla Countdown voidaan palauttaa toonikan korvaamiseen terssisukuisilla soinnuilla $t \mathrm{G}$ ja $\mathrm{TG}$, joiden eteen on lisätty välidominantit sekä mahdollisesti välisubdominantit. Esim. David Baker $(1994,63)$ on selittänyt Countdownin huomattavasti monimutkaisemmin sointujen välisten intervallien perusteella.

\section{Johtopäätökset}

Diether de la Motten harmoniaopin soveltaminen jazziin osoittautui varsin hedelmälliseksi lähestymistavaksi. Jazzissa käytetty pohjasävelmerkintä on nimittäin tarkoitettu enemmän muusikkoja kuin analyytikkoja varten, joten funktiomerkintöjen käyttö auttaa paremmin hahmottamaan jazzin harmonisia linjoja.

On kuitenkin muistettava, että funktioanalyysia voidaan kunnolla soveltaa vain tonaaliseen jazziin. Myös tonaalisessa jazzissa funktiomerkintöjen käytössä on omat ongelmansa, sillä niistä tulee varsin monimutkaisia ja siten hankalampia lukea, jos niihin merkitään kaikki sointujen lisä- ja muunnesävelet. Tässä tutkimuksessa lisä- ja muunnesävelet eivät tuottaneet ongelmia, sillä analyysin kohteena oli korvaussääntöjen sointumerkinnät. Käytännön musiikkia analysoitaessa lisä- ja muunnesävelten käsitteleminen on kuitenkin selvästi hankalampaa.

Jazzin sointukorvausten tutkimuksessa funktioanalyysista oli selvää hyötyä, sillä suurimmalle osalle jazzkirjallisuuden korvaussäännöistä löytyi funktionaalinen perusta: korvaava sointu toimi joko samassa funktiossa kuin alkuperäinen sointu tai oli sille terssisukuinen. Varsin usein korvaava sointu ei kuitenkaan esiintynyt funktiomerkinnän mukaisessa perusmuodossaan, vaan sitä oli muunnettu. Esimerkiksi vähennettyyn sointuun perustuvia dominantin korvauksia oli useimmiten muunnettu siten, että ne soivat kuten dominanttiseptimisointu. Eräänä syynä tähän voi olla se, että jazzissa korvaavat soinnut on löydetty enemmän kokeilujen kuin teoreettisen pohdinnan kautta. Dominanttiseptimisointu on jazzin tärkein sointu, joten muusikot ovat soittaneet sitä silloinkin, kun teoreettisesti ajatellen olisi voitu käyttää vähennettyä sointua.

Funktioanalyysin ansiosta suurin osa jazzkirjallisuudessa esiintyvistä sointukorvauksista voidaan redusoida seuraaviksi säännöiksi:

1) Dominanttiseptimisointu $D^{7}$ voidaan korvata vähennetyllä soinnulla ${ }^{\mathrm{s}} \mathrm{D}^{\mathrm{v}}$ tai sen muunnoksilla. Jos sointua muunnetaan alentamalla jokin soinnun sävelistä, muunnettu sävel on yleensä pohjasävelenä, jolloin sointu soi kuten dominanttiseptimisointu. Yleisin muunnos on ${ }^{t} \mathrm{D}^{\mathrm{D}}{ }_{3>}$ eli ns. tritonuskorvaus. Vähennetyn soinnun säveltä voidaan myös ylentää, jolloin saadaan puolivähennetty sointu.

2) Toonikasointu voidaan korvata vastakkaissoinnulla $\mathrm{Tg}$ tai paralleelilla $\mathrm{Tp}$. Lisäksi voidaan kokeilla toonikan korvaamista muilla terssisukuisilla soinnuilla, kuten $\mathrm{tG}$ tai $\mathrm{TG}$. 
3) Yleisimmin subdominanttina käytetään duurissa subdominanttiparalleelia $\mathrm{Sp}^{7}$ ja mollissa sointua $s_{6}^{5}$. Kuitenkin subdominanttina voi toimia periaatteessa mikä tahansa subdominanttitehoinen sointu, kuten $S, S_{6}, S_{3}, S_{6}, S_{6>}$ tai s ${ }_{6>}^{5}$.

4) Soinnun eteen voidaan lisätä välidominantti, joka voi olla tavallinen dominanttiseptimisointu tai mikä tahansa dominantin korvaava sointu. Lisäksi välidominanttina käytetään hyvin yleisesti II-V-sointukulkua.

5) Minkä tahansa dominanttiseptimisoinnun eteen voidaan lisätä siihen II-Vsuhteessa oleva molliseptimisointu.

Ylläolevat säännöt kattavat suurimman osan jazzkirjallisuudessa esiintyvistä sointukorvauksista. Kirjallisuudessa esiintyy kuitenkin joitakin korvaussääntöjä, joita ei pysty selittämään funktioanalyysin avulla, sillä ne perustuvat asteikkopohjaiseen ajatteluun. Asteikkopohjaisessa improvisoinnissa korvaavia sointuja ovat kaikki ne soinnut, joiden yhteydessä soitetuissa asteikoissa on enharmonisesti samat sävelet. Asteikkopohjaisen improvisoinnin kautta johdettuja korvaussääntöjä voi käyttää solistisessa improvisoinnissa melko vapaasti, mutta säestykseen sovellettaessa pitää olla varovainen, sillä asteikkoihin perustuvat korvaavat soinnut saattavat muuttaa ratkaisevasti sävellyksen funktionaalista harmoniaa.

Funktiomerkintöjen avulla saatiin siis muodostettua yksinkertainen ja yhtenäinen teoria sointukorvauksista. Teoriaa ei voi kuitenkaan suoraan soveltaa musiikin esittämiseen, sillä funktiomerkintöjä ei ole tarkoitettu soittamista varten. Kun sääntöjen avulla johdetaan sointukorvauksia, lopputulos olisi aina syytä muuntaa pohjasävelmerkintään perustuvaksi sointumerkinnäksi. Funktiomerkintöihin perustuvissa korvaussäännöissä on niiden yksinkertaisuuden lisäksi kuitenkin myös se etu, että niiden avulla voidaan johtaa sellaisiakin sointukorvauksia, joita ei esiinny jazzkirjallisuudessa.

Jazzia analysoitaessa on tärkeätä muistaa, että se on pohjimmaltaan kuulonvaraista musiikkia. Myös edellä esitettyjä korvaussääntöjä tulee pitää enemmän ohjeina kuin ehdottomina sääntöinä. Korvaussäännöt ovat ainoastaan pohja musiikillisille kokeiluille. Lopullinen valinta pitää aina tehdä sen mukaan, miltä eri vaihtoehdot kuulostavat.

\section{Lähteet}

Baker, David 1990. Jazz improvisation. Rottenburg: Advance Music.

Baker, David 1994. 'Extending The Coltrane Changes." Down Beat, March 1994, 63.

Coker, Jerry 1987. Improvising Jazz. First Fireside Book Edition. New York: Simon \& Schuster Inc.

Collier, Graham 1977. Jazz. Gambridge: Gambridge University Press. 
Fowler, William 1977. "How to energize chord progression." Part I. Down Beat, July 14, 1977, 60-61.

Henriksson, Juha 1995. Korvaavien sointujen käyttö jazzissa. Pro gradu -tutkielma, Helsingin yliopisto, musiikkitieteen laitos (painamaton).

Jeanquartier, Andre 1984. 'Kritische Anmerkungen zum 'Lydian Chromatic Concept'. Ein Vergleich zwischen George Russells Konzept und dem DurMoll-System."Jazzforschung / Jazzresearch 16, 9-41.

Liebman, David 1991. A Chromatic Approach to Jazz Harmony and Melody. Rottenburg: Advance Music.

Motte, Diether de la 1987. Harmoniaoppi. Suomentanut Mikko Heiniö. Musiikkitieteen kirjasto 4. Helsinki: Suomen Musiikkitieteellinen Seura.

Potter, Gary M. 1989. The unique role of bVII7 in bebop harmony. Jazzforschung / Jazzresearch 21, 35-47.

Ricigliano, Daniel 1969. Popular and Jazz Harmony. Revised edition. New York: Donato.

Rinzler, Paul 1989. Jazz Arranging and Performance Practice. A Guide for Small Ensembles. Metuchen, N.J., \& London: The Scarecrow Press.

Russell, George 1959. The Lydian Chromatic Concept of Tonal Organization. New York: Concept Publishing.

Strunk, Steven 1988. "Harmony." The New Grove Dictionary of Jazz, Barry Kern (ed.). Volume One, 485-496. London: MacMillan Press Limited. 